\title{
FLEA BEETLE POPULATIONS AND ECONOMIC YIELD OF OKRA AS INFLUENCED BY NITROGEN AND 2, 3-DIHYDRO-2, 2-DIMETHYL BENZOFURAN
}

\author{
B.C. ECHEZONA, J.E. ASIEGBU and IZUAGBA, A.A \\ ${ }^{1}$ Department of Crop Science, University of Nigeria, Nsukka, Nigeria \\ Corresponding author: chezbon2001@yahoo.co.uk
}

(Received 9 May, 2010; accepted 24 August, 2010)

\begin{abstract}
Nitrogen fertilisation and carbofuran applications impact plants, yet few studies examine their general impact on plant performance and plant susceptibility to insect pests and diseases when applied together. The performance of okra (Abelmoschus esculentus L. Moench) and infestations by flea beetles in relation to nitrogen and carbofuran applications were, therefore, evaluated under a humid tropical environment. Treatments comprised of combinations of four rates of 2, 3-dihydro-2, 2-dimethylbenzofuran or carbofuran (0.0, 0.5, 1.0 and $\left.1.5 \mathrm{~kg} \mathrm{ha}^{-1}\right)$ and four levels of $\mathrm{N}$ - fertiliser $\left(0,40,80\right.$ and $\left.120 \mathrm{~kg} \mathrm{ha}^{-1}\right)$. The presence of Podagrica uniformis was recorded much earlier on the plants than Nisotra sjostedti. The population of either flea beetle remained lower throughout the vegetative than the reproductive phase. While $\mathrm{N}$ fertilisation resulted in higher insect count than where no $\mathrm{N}$ was added, carbofuran at $1.0 \mathrm{~kg} \mathrm{ha}^{-1}$ and above significantly $(\mathrm{P}<0.05)$ depressed the flea beetle populations up to 5 weeks after planting. Differences in the carbofuran and $\mathrm{N}$ interaction had no statistical significance on insect count. All cases of applied carbofuran and nitrogen increased earliness to maturity, plant height, total fruit number, fruit weight, fruit yield and net marginal returns. Higher doses of carbofuran in combination with nitrogen significantly increased earliness to plant maturity, fruit number per plant, fruit yield and net marginal returns. The best fruit yield was attained by combining $1.0 \mathrm{~kg} \mathrm{ha}^{-1}$ carbofuran with $80 \mathrm{~kg} \mathrm{~N} \mathrm{ha}^{-1}$, while the best economic return was achieved by combining 0.5 $\mathrm{kg} \mathrm{ha}^{-1}$ carbofuran with $80 \mathrm{~kg} \mathrm{ha}^{-1}$. Incidence of mosaic disease was suppressed with increasing doses of carbofuran or decreasing doses of nitrogen.
\end{abstract}

Key Words: Abelmoschus esculentus, Carbofuran, Nisotra sjostedti, Podagrica uniformis

\section{RÉSUMÉ}

La fetilisation azotée ainsi que l'application du carbofuran affectent les plantes, mais peu d'études examinent leur impact sur la performance et la susceptibilité des plantes aux pestes et maladies, lorsque les deux sont appliqués ensemble. La performance d'Okra (Abelmoschus esculentus L.Moench) et des infestations par des coléoptères en relation avec l'application de l'azote et du carbofuran étaient ainsi évaluées sous un environnement à climat humide tropical. Les traitements comprenaient une combinaison de quatre doses de 2, 3-dihydro-2, 2dimethylbenzofuran ou carbofuran $(0.0,0.5,1.0$ et $1.5 \mathrm{~kg}$ ha- 1$)$ et quatre niveaux d' engrais $\mathrm{N}(0,40,80$ et $120 \mathrm{~kg}$ ha-1). La présence de Podagrica uniformis sur les plantes était observée un peu plus tôt que le Nisotra sjostedti. La population de coléoptères était restée plus basse dans la phase végétative que dans la phase reproductive. Alors que le nombre d'insects était plus élevé dans les traitement sous fertilization azotée que dans le contrôle, la dose de plus ou moins $1.0 \mathrm{~kg} \mathrm{ha}^{-1}$ de carbofuran avait significativement $(\mathrm{P}<0.05)$ réduit les populations de coléoptères jusqu'à cinq semaines après le semis. Aussi, il n'yavait pas eu de difference significative en terme d'interaction entre le carbofuran et d'azote appliqués. Dans tous les cas, le carbofuran et l'azote avait eu un effet sur la maturation précoce, la hauteur de plants, le nombre total de fruits, le poids de fruits, le rendement en fruits ainsi que sur des bénéfices marginaux nets. La combinaison de doses élevées de carbofurant et d'azote avait affecté significativement la susceptibilité de la plant à la maturation précoce, le nombre de fruits par plant, le rendement en fruits et les bénéfices marginaux nets. Le meilleur rendement en fruit était realisé par la combinaison de $1.0 \mathrm{~kg} \mathrm{ha}^{-1} \mathrm{de}$ carbofuran 
avec $80 \mathrm{~kg} \mathrm{~N} \mathrm{ha}^{-1}$, alors que la combinaison de $0.5 \mathrm{~kg} \mathrm{ha}^{-1}$ de carbofuran avec $80 \mathrm{~kg} \mathrm{ha}^{-1}$ d'azote était la meilleure du point de vue de la rentabilité économique. L’incidence de la maladie de mosaïque était controlée soit par l'augmentation des doses de carbofuran ou par la diminution des doses d'Azote.

Mots Clés: Abelmoschus esculentus, Carbofuran, Nisotra sjostedti, Podagrica uniformis

\section{INTRODUCTION}

Okra (Abelmoschus esculentus (L.) Moench) is an important vegetable crop almost consumed worldwide. The tender fruits, leaves and succulent shoots are consumed, either in fresh or dried forms (Arapitsas, 2008). The fruit is a greenish capsule, slightly curved, six-chambered pods of fibrous texture, containing numerous seeds (Lengsfeld et al., 2004).The thick slimy juice of the fruits makes it a relish in the preparation of soup for pounded yam and foofoo. It is also an important source of fibre and thus a multipurpose crop.

Okra consumption among other fruit vegetables were found beneficial in moderating blood pressure, fibrinogen concentration and plasma viscosity in Nigerian hypertensives (Adebawoo et al., 2007)

Problems of okra production in Nigeria are insect pest infestations, disease incidence and poor soil nutrient level. It has become a common sight to find numerous perforations on the leaves of okra usually caused by herbivorous insects, which is almost being accepted as a common feature of the crop (Egwuatu, 1982). Youdeowei (2002) has documented insects of primary importance in the cultivation of okra crop. Egwuatu (1982) noted that Podagrica uniformis, Jacoby and Nisotra sjostedti, Jacoby (Col.: Chrysomelidae) are the most destructive insect species at Nsukka, Nigeria.

Okra mosaic virus (OMV), which is transmitted by insects belonging to Podagrica species, has been reported from Côte d' Ivoire, Kenya, Nigeria and Sierra Leone in Africa (Brunt et al., 1996; Fajinmi and Fajinmi, 2010). The flea beetles and Syagrus calcaratus (Fab.) (Col.: Chrysomelidae) have also been implicated in the transmission of OMV in okra (Fajinmi and Fajinmi, 2010). But farmers ignore such diseases because they lack information on their control (Ndunguru and Rajabu, 2002).
In a field trial with other insecticides for the control of okra flea beetle, Egwuatu (1982), found 2,3-dihydro-2, 2-dimethylbenzofuran (carbofuran) as the most effective at $1.5 \mathrm{~kg}$ a.i. $\mathrm{ha}^{-1}$ both in terms of yield improvement and insect reduction compared to other insecticides used. Carbofuran and other systemics have also been reported to enhance the growth and yield of treated plants to varying extents (Ceccon et al., 2004; Van Hezewijk et al., 2008).

Several researchers have also recognized nitrogen fertilisation as a booster of crop growth, development and yield in the presence of favourable environmental influences (Groot et al., 2003; Van Hezewijk et al., 2008; Prvulovic et al., 2010; Useche and Shipley, 2010).

Besides its effect on growth, development and yield of crops, application of nitrogen has also been reported to influence the susceptibility of plants to pests and diseases (Youdeowei, 2002; Van Hezewijk et al., 2008). But there is paucity of information on the effect of combined application of $\mathrm{N}$ fertilisation and carbofuran treatment on crop development, pest and disease incidence. This may eventually influence their application rates especially when applied together. The objectives of this study were to:

(i) evaluate the phenological relationship between okra growth stages and the incidence of okra flea beetles ( $P$. uniformis and N. sjostedti);

(ii) determine the minimum effective rates of carbofuran and/or nitrogen application for the control of the flea beetles of okra; and

(iii) assess the influence of carbofuran and/or $\mathrm{N}$-fertilisation on the growth and yield of okra. 


\section{MATERIALS AND METHODS}

The study was carried out at the Teaching and Research farm of Faculty of Agriculture, University of Nigeria, Nsukka (Lat. $06^{\circ} 52^{1} \mathrm{~N}$, Long. $07^{\circ} 24^{1} \mathrm{E}$; elevation $447.26 \mathrm{~m}$ above mean sea level) between 2005 and 2006 cropping seasons. Jungerius (1964) and Enwezor et al. (1989) classified the soil of the ecozone as Typic Ultisol. From long term meteorological data, the annual rainfall was normally bimodal with peaks in July and September.

Treatments involve factorial combinations of four rates of Furadan $3 \mathrm{G}^{\circledR}$ (a.i.= carbofuran) $(0.0$, $0.5,1.0$ and $1.5 \mathrm{~kg} \mathrm{a}$. i. ha $\left.{ }^{-1}\right)$ and four levels of nitrogen (0, 40, 80 and $120 \mathrm{~kg} \mathrm{ha}^{-1}$ ) laid out in randomised complete block design, with three replications. The site was mowed, ploughed and harrowed to a fine tilth. Each of the three blocks was divided into 16 plots, each measuring $2.7 \mathrm{~m} \mathrm{x}$ $1.8 \mathrm{~m}$ with $0.5 \mathrm{~m}$ pathways between the plots and $1.0 \mathrm{~m}$ between blocks.

Okra seeds of 'cv' “Awgu Early”, obtained from Ministry of Agriculture, Market Garden, Enugu were dressed with Apron plus ${ }^{\circledR}$ (metalaxyl + carboxin + furathiocarb) at the rate of $10 \mathrm{~g} 2$ $\mathrm{kg}^{-1}$ of seeds to give the seedlings the initial prophylactic treatment. Planting was done on raised beds, two seeds being drilled per hole at about $3 \mathrm{~cm}$ depth. The seedlings were later thinned down to one plant per stand after the first two leaves had properly emerged. Spacing was at $60 \mathrm{~cm}$ between rows and $45 \mathrm{~cm}$ within the row giving a population of 37,037 plants per hectare.

Blanket applications of single super phosphate and muriate of potash were made at the rates of $30 \mathrm{~kg} \mathrm{P} \mathrm{ha}^{-1}$ and $90 \mathrm{~kg} \mathrm{~K} \mathrm{ha}^{-1}$ to each of the plots at the 3-leaf stage of the plants, 15 days after planting (DAP). Furadan (carbofuran) was weighed out at the appropriate rates and placed in the drilling holes of the seeds at planting. Nitrogen as urea, was applied at 3-leaf stage (15 DAP) using various rates and to appropriate plots.

The insect counts were based on the four inner plants per plot. Plants showing mosaic symptoms expressed as vein clearing, vein banding, mottled and mosaic patterns were counted from 8 weeks after planting. This was expressed as the percentage of the four inner plants per plot showing this symptom. Observations on yield and yield components were based on days to $50 \%$ flowering, plant height at 50 DAP, fruit number, weight per fruit and fruit yield per hectare.

The net profit after deducting cost of insecticide, fertiliser and labour inputs was computed and recorded as net marginal returns.

Data collected were subjected to analysis of variance according to the procedure outlined by Steel and Torrie (1980). Insect count and per cent disease incidence were subjected to square root and arc sin transformations, respectively, before analysis of variance were carried out. Detection of differences among treatment means was carried out using the Least significant difference (LSD) procedure.

\section{RESULTS}

The preponderant insect pests of major importance observed were Podagrica uniformis, Jacoby and Nisotra sjostedti, Jacoby (Coleoptera; Chrysomelidae). Arrival of the species on okra plant started 3 WAP in plots where carbofuran was not applied, and where the highest $\mathrm{N}$ rate (120 kg ha-1) was applied (Table 1). Other plots did not show infestation until 5 WAP. At 5 WAP, carbofuran at 1.0 or 1.5 rates depressed insect pest infestation significantly $(\mathrm{P}<0.05)$.

Nitrogen application resulted in higher insect population than where no $\mathrm{N}$ was applied. Interaction of the two treatments did not produce significant $(\mathrm{P}>0.05)$ effects. At 7 or 9 WAP, insect pest infestation had become more appreciable than at the earlier stages of plant development. At this stage, differences in the pest population with $\mathrm{N}$ fertilisation or with carbofuran treatment were not significant. However, there was an evidence of higher pest population with increasing $\mathrm{N}$ - treatment, while especially $1.5 \mathrm{~kg} \mathrm{ha}^{-1}$ of carbofuran appeared to depress the pest population.

The variations in population of the two major insect pest Podagria uniformis and Nisotra sjostedti at different stages of okra plant development are summarised in Figure 1. Nisotra sjostedti infestation on okra plants occurred one 
TABLE 1. Flea beetle density as influenced by carbofuran and nitrogen at various stages of growth in Nigeria

\begin{tabular}{|c|c|c|c|c|c|c|}
\hline \multirow[t]{2}{*}{ Weeks after planting } & \multirow[t]{2}{*}{ Carbofuran rates $\left(\mathrm{kg} \mathrm{ha}^{-1}\right)$} & \multicolumn{4}{|c|}{ Nitrogen levels $\left(\mathrm{kg} \mathrm{ha}^{-1}\right)$} & \multirow[t]{2}{*}{ Mean } \\
\hline & & 0 & 40 & 80 & 120 & \\
\hline \multirow{4}{*}{3} & 0.0 & 0.0 & 0.0 & 0.0 & 7.0 & 1.8 \\
\hline & 0.5 & 0.0 & 0.0 & 0.0 & 0.0 & 0.0 \\
\hline & 1.0 & 0.0 & 0.0 & 0.0 & 0.0 & 0.0 \\
\hline & 1.5 & 0.0 & 0.0 & 0.0 & 0.0 & 0.0 \\
\hline \multirow{4}{*}{5} & 0.0 & 3.3 & 3.6 & 7.2 & 4.3 & 4.6 \\
\hline & 0.5 & 3.4 & 3.5 & 7.0 & 3.7 & 4.4 \\
\hline & 1.0 & 0.0 & 1.1 & 0.0 & 0.2 & 0.3 \\
\hline & 1.5 & 0.5 & 0.7 & 0.0 & 0.7 & 0.5 \\
\hline \multirow{4}{*}{7} & 0.0 & 12.8 & 25.1 & 16.9 & 18.0 & 18.2 \\
\hline & 0.5 & 10.0 & 36.2 & 20.9 & 23.2 & 22.6 \\
\hline & 1.0 & 13.0 & 17.2 & 17.9 & 18.0 & 16.8 \\
\hline & 1.5 & 8.1 & 16.7 & 8.1 & 15.9 & 12.2 \\
\hline \multirow{4}{*}{9} & 0.0 & 9.4 & 57.3 & 33.3 & 40.2 & 35.1 \\
\hline & 0.5 & 41.8 & 78.7 & 62.9 & 29.6 & 53.3 \\
\hline & 1.0 & 21.0 & 26.1 & 27.5 & 98.7 & 43.3 \\
\hline & 1.5 & 34.3 & 33.7 & 18.7 & 29.1 & 29.0 \\
\hline
\end{tabular}

Weeks after planting

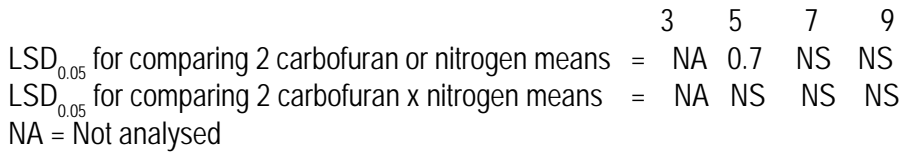

week later than $P$. uniformis. Except for a lower value at 8 WAP, the population of $N$. sjostedti was always more abundant than $P$. uniformis.

Generally, the flea beetle count was relatively low at the vegetative stage of okra, but increased progressively through the flower, fruit set and fruit harvest stages. It peaked at the senescence stage.

The number of days to $50 \%$ flowering was progressively reduced with increasing rates of carbofuran application (Table 2). All cases where carbofuran was applied had significantly less days to flowering than where no carbofuran was applied. Where $1.5 \mathrm{~kg}$ a.i. of carbofuran was applied attained $50 \%$ flowering in significantly $(\mathrm{P}<0.05)$ less okra days than where only 0.5 a.i. was applied.

Application of fertiliser $\mathrm{N}$ progressively depressed the number of days taken to attain $50 \%$ flowering. Combinations of 80 to $120 \mathrm{~kg} \mathrm{~N}$ ha $^{-1}$ with 1.0 - $1.5 \mathrm{~kg}$ a.i. of carbofuran generally reduced the number of days to flowering than combinations of low rates of carbofuran and $\mathrm{N}$ fertiliser.

All cases of applied carbofuran did not differ from each other in their effects on plant height, but produced significantly $(\mathrm{P}>0.05)$ taller plants than where no carbofuran was applied. Nitrogen generally produced significantly $(\mathrm{P}<$ 0.05 ) taller plants than the control. Differences in plant height among treatment combinations were not significant. However, there was an evident trend of taller plants with combinations of higher rates of carbofuran and nitrogen than their lower rates.

The incidence of mosaic symptoms were progressively depressed by application of carbofuran, while application of nitrogen significantly increased the incidence of the disease. The disease incidence was always more 


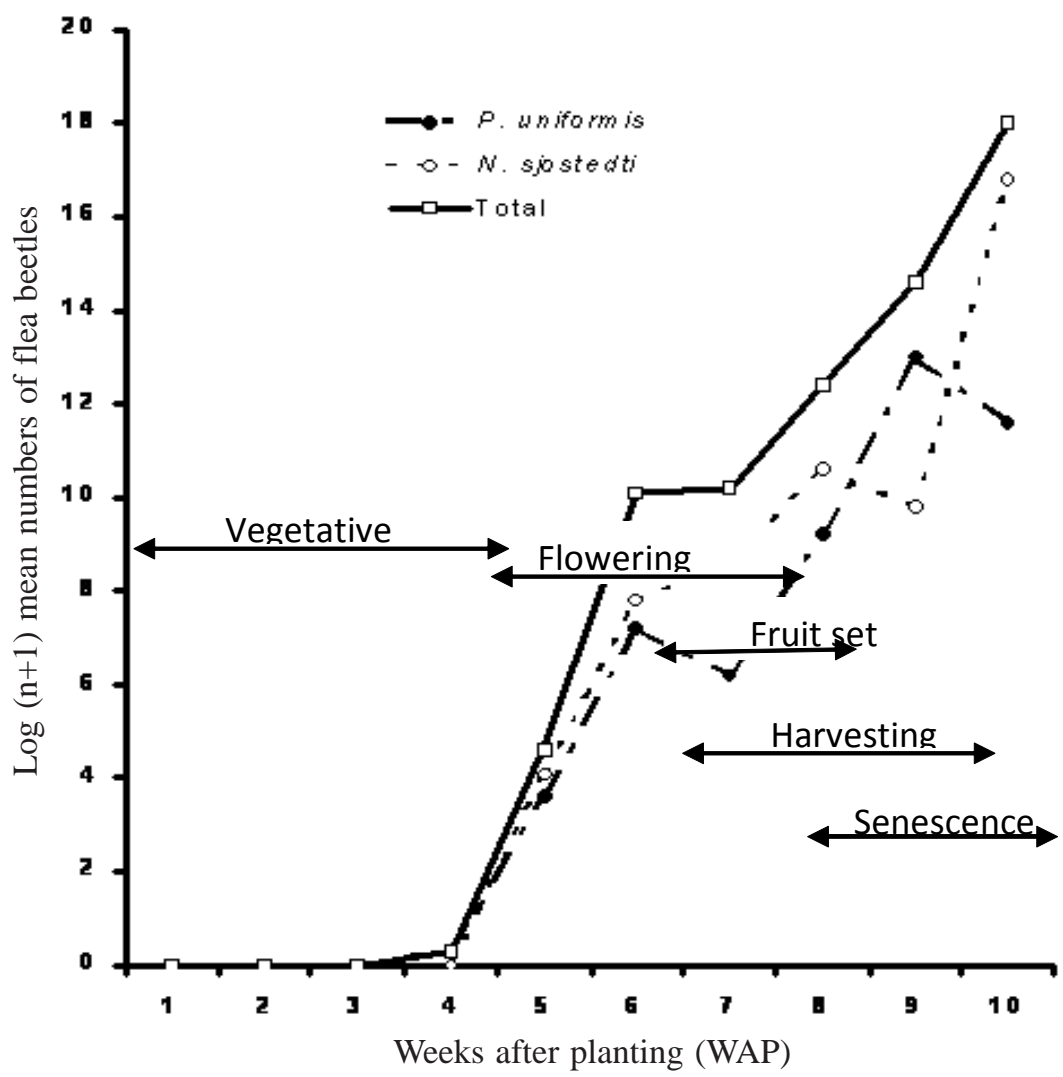

Figure 1. Variation in the density of Podagrica uniformis and Nisotra sjostedti with advancing age of Okra 'cv' Awgu early.

prevalent where no carbofuran or the rate of 0.5 $\mathrm{kg}$ a.i. was applied, especially where high rates of nitrogen were used. The combination of $80 \mathrm{~N}$ ha $^{-1}$ and 1.0 or $1.5 \mathrm{~kg}$ a.i. of carbofuran showed a better control of the okra mosaic disease.

Application of higher rates of carbofuran produced more $(\mathrm{P}<0.05)$ fruits than where no carbofuran or 0.5 rate was applied (Table 3 ). Nitrogen treated plants also produced more fruits than untreated plants. Combinations of $80-120$ $\mathrm{kg} \mathrm{N} \mathrm{ha}^{-1}$ with $1.5 \mathrm{~kg}$ a.i. ha- ${ }^{-1}$ carbofuran produced the highest fruit numbers. Application of carbofuran progressively increased the fruit weight of okra per fruit. Application of $1.5 \mathrm{~kg}$ a.i. $\mathrm{ha}^{-1}$ showed no difference with application of 1.0 $\mathrm{kg}$ a.i. ha ${ }^{-1}$. However, $80 \mathrm{~kg} \mathrm{~N}^{-1}$ significantly increased fruit weight over the $\mathrm{N}$ control or at 40 $\mathrm{kg} \mathrm{N} \mathrm{ha}^{-1}$. Weight per fruit appeared highest with a combination of $1.5 \mathrm{~kg}$ a. i. ha ${ }^{-1}$ of carbofuran and $80 \mathrm{~kg} \mathrm{~N} \mathrm{ha}^{-1}$. The effects of carbofuran and $\mathrm{N}$ application on fruit $\left(\mathrm{kg} \mathrm{ha}^{-1}\right)$ followed similar trends as their effects on weight per fruit. Fruit yield and economic return improvements did not go beyond the rates of $1.0 \mathrm{~kg}$ a.i. of carbo furan or $80 \mathrm{~kg} \mathrm{~N} \mathrm{ha}^{-1}$. Combined applications of $0.5-$ $1.5 \mathrm{~kg}$ a.i. of carbofuran and $80 \mathrm{~kg} \mathrm{~N} \mathrm{ha}{ }^{-1}$ appeared to produce the best yield and economic return.

\section{DISCUSSION}

The greater preponderance of flea beetles during the reproductive phase of the plant compared with the vegetative phase could be attributed to the increasing abundance of food sources. Such food sources on okra plant may include flower buds, flowers and pods that were more in abundance at the reproductive stage of the plant compared with the vegetative phase. This result supports the thesis of greater insect aggregations with more sources of food supply (Egwuatu and Taylor, 1976). The choice of flower buds, 
TABLE 2. Effect of carbofuran and nitrogen on days to $50 \%$ flowering, plant height at 50 days after planting and incidence of okra mosaic disease in Nigeria

\begin{tabular}{|c|c|c|c|c|c|c|}
\hline \multirow[t]{2}{*}{ Parameter } & \multirow[t]{2}{*}{ Carbofuran rates $\left(\mathrm{kg} \mathrm{ha}^{-1}\right)$} & \multicolumn{4}{|c|}{ Nitrogen levels $\left(\mathrm{kg} \mathrm{ha}^{-1}\right)$} & \multirow[t]{2}{*}{ Mean } \\
\hline & & 0 & 40 & 80 & 120 & \\
\hline \multirow[t]{4}{*}{ Days to $50 \%$ flowering } & 0.0 & 62.3 & 55.3 & 50.0 & 45.7 & 53.3 \\
\hline & 0.5 & 58.3 & 53.3 & 42.0 & 41.0 & 48.7 \\
\hline & 1.0 & 58.3 & 51.0 & 41.0 & 41.0 & 47.8 \\
\hline & 1.5 & 55.0 & 51.0 & 40.0 & 40.3 & 46.6 \\
\hline \multirow[t]{4}{*}{ Plant height (cm) } & 0.0 & 23.5 & 31.0 & 30.0 & 32.1 & 29.1 \\
\hline & 0.5 & 28.8 & 43.3 & 31.7 & 31.3 & 35.0 \\
\hline & 1.0 & 29.3 & 33.3 & 34.9 & 42.4 & 34.9 \\
\hline & 1.5 & 23.3 & 34.3 & 36.6 & 40.1 & 34.8 \\
\hline \multirow[t]{4}{*}{ Okra mosaic disease incidence } & 0.0 & 13.3 & 23.3 & 48.3 & 96.7 & 45.4 \\
\hline & 0.5 & 13.3 & 20.0 & 15.0 & 66.7 & 28.8 \\
\hline & 1.0 & 3.3 & 3.3 & 10.0 & 16.7 & 8.3 \\
\hline & 1.5 & 3.3 & 3.3 & 0.0 & 13.3 & 5.0 \\
\hline \multirow{3}{*}{$\begin{array}{l}\mathrm{LSD}_{0.05} \text { for carbofuran or nitrogen means } \\
\mathrm{LSD}_{0.05} \text { for carbofuran } \mathrm{x} \text { nitrogen means }\end{array}$} & Days to $50 \%$ flower & & Planthei & \multicolumn{3}{|c|}{ Mosaic disease incidence } \\
\hline & ans & & 4.3 & \multicolumn{3}{|c|}{0.5} \\
\hline & ans & & NS & \multicolumn{3}{|c|}{1.1} \\
\hline
\end{tabular}

flowers, succulent pods as well as matured pods for food by the flea beetles has been documented by Schippers (2000).

The relative abundance of Nisotra sjostedti over Podagrica uniformis in all the sampling period suggests a stronger preference for okra plant parts by $N$. sjostedti than P. uniformis. This may have accounted for the eventual relative displacement of the latter by the former. This displacement might be due to interspecific competition between the two species. The relative abundance of these species, however, may be an important response in elucidating their feeding behaviours as well as their biology.

The differential efficacies of carbofuran rates on flea beetle control up to 5 weeks after planting (WAP) was attributed to the powerful systemic mode of action of the soil applied insecticide. This action appeared to wane down after 5 WAP and, thereafter became ineffective. On tropical soils, the half-life of carbofuran ranges between 30 and 60 days (Anon, 1972). With carbofuran, Egwuatu (1982) recommended that a single dose at planting holes would be most meaningful. Such single dose application is expected to obviate possible residue problems during the fruiting periods that may arise as a result of repeated applications.

Promotion of plant growth as recorded in this study with carbofuran or nitrogen treatment could account for the significant yield improvement achieved by the two treatments. According to Ceccon et al.(2004) and Van Hezewijk et al. (2004), carbofuran and other systemics are known to promote growth and enhance the yield of the affected crops. Similarly, Groot et al. (2003); Van Hezewijk et al. (2008) and Prvulovic et al. (2010), recorded that nitrogen fertilisation promotes growth and yield of some crops at some levels of application. Taller plants could mean more internodes and nodes for possible pod attachments and, therefore, better chances for more fruit yield. Although there was a progressive trend of heavier fruits with increasing combined doses of carbofuran and nitrogen, significant differences were only detected among these traits for both.

The non-production of significant desired synergistic effect on crop growth and fruit weight by the combined applications of nitrogen and carbofuran might be attributed to the 
TABLE 3. Effect of carbofuran and $\mathrm{N}$ fertiliser applications on okra yield components and net margin

\begin{tabular}{|c|c|c|c|c|c|c|}
\hline \multirow[t]{2}{*}{ Parameter } & \multirow[t]{2}{*}{ Carbofuran rates $\left(\mathrm{kg} \mathrm{ha}^{-1}\right)$} & \multicolumn{4}{|c|}{ Nitrogen levels $\left(\mathrm{kg} \mathrm{ha}^{-1}\right)$} & \multirow[t]{2}{*}{ Mean } \\
\hline & & 0 & 40 & 80 & 120 & \\
\hline \multirow[t]{4}{*}{ Fruit numberper plant } & 0.0 & 9.5 & 11.9 & 9.7 & 9.3 & 10.1 \\
\hline & 0.5 & 11.9 & 11.3 & 12.5 & 7.3 & 10.8 \\
\hline & 1.0 & 10.8 & 17.1 & 14.7 & 12.3 & 13.7 \\
\hline & 1.5 & 11.3 & 16.8 & 18.2 & 20.1 & 16.6 \\
\hline \multirow[t]{4}{*}{ Weight per fruit (g) } & 0.0 & 22.2 & 24.7 & 34.6 & 29.1 & 27.7 \\
\hline & 0.5 & 30.5 & 27.5 & 34.5 & 35.0 & 31.9 \\
\hline & 1.0 & 31.5 & 35.9 & 42.6 & 43.5 & 38.4 \\
\hline & 1.5 & 35.8 & 37.3 & 44.9 & 42.1 & 40.0 \\
\hline \multirow[t]{4}{*}{ Total fruit yield ( $\mathrm{tha}^{-1}$ ) } & 0.0 & 8.9 & 9.9 & 13.6 & 11.7 & 11.0 \\
\hline & 0.5 & 12.6 & 11.0 & 13.8 & 14.0 & 12.9 \\
\hline & 1.0 & 12.6 & 14.4 & 17.1 & 17.5 & 15.4 \\
\hline & 1.5 & 14.3 & 15.3 & 18.0 & 16.1 & 15.9 \\
\hline \multirow[t]{4}{*}{ Net margin $\left(A h a^{-1}\right)^{\star}$} & 0.0 & 709120.0 & 789105 & 1103223 & 924541.1 & 881497.2 \\
\hline & 0.5 & 957837 & 860755 & 1081219 & 1095818 & 998907.1 \\
\hline & 1.0 & 973497 & 1112682 & 1332719.6 & 1351478 & 1192594 \\
\hline & 1.5 & 1095173.3 & 1170038 & 1382289.6 & 1287981.1 & 1233871 \\
\hline \multicolumn{2}{|c|}{$\mathrm{LSD}_{0.05}$ for comparing 2 carbofuran or 2 nitrogen means } & $\begin{array}{r}\text { Fruit I } \\
2.5\end{array}$ & & $\begin{array}{l}\text { Fruit wt } \\
6.1\end{array}$ & $\begin{array}{c}\text { Total yield } \\
2.4\end{array}$ & $\begin{array}{l}\text { Net margin } \\
194138.2\end{array}$ \\
\hline \multicolumn{2}{|c|}{$\begin{array}{l}\mathrm{LSD}_{0.05} \text { for comparing } 2 \text { carbofuran } \times \text { nitrogen means } \\
{ }^{*} \mathrm{~A} 120=\$ 1 \text { (USD) }\end{array}$} & 5.0 & & - & 4.0 & 388276.4 \\
\hline
\end{tabular}

uncomplimentary effect of the treatment combinations. The possession of different metabolites and/or mechanisms by the two treatments possibly affords them different metabolic pathways especially when applied together. The different pathways may possibly result in the no-significant plant growth and fruit weight improvement effect that resulted when both were applied together. The growth metabolites of carbofuran are carbofuran phenol and 3-hydroxyl carbofuran (Trevisan et al., 2004), while the growth mechanism in nitrogen is by protein synthesis and carbohydrate utilisation (Andrew et al., 2007).

The significant reduction in the mosaic symptom expression on the carbofuran treated plots, even with the in-undated populations of the flea beetles recorded after 5 WAP, suggests that control of disease vectors at the early plant growth produces a better yield and suppression of disease incidence than control in the later stages of crop growth. Marchie (1993) reported that okra mosaic virus OKMv infection at six or more weeks after planting did not significantly affect okra yield. Fajinmi and Fajinmi (2010), also reported that inoculation of okra plants with OKMv 14 and 21 days after emergence (DAE) significantly reduced the weight of fruits per plant compared with those inoculated 28 DAP or noninoculated control. They, however, concluded that flea beetles have been seriously implicated in the transmission of okra mosaic virus to okra plants in the field.

The progressive increase in the incidence of insect pests and mosaic disease expression with increased $\mathrm{N}$ fertilisation was attributed to the increased hydration and succulence of the plant tissues. Draycott and Christenson (2003) reported that excessive application of $\mathrm{N}$ increases tissue hydration and succulence and could therefore predispose such organs to more pest and disease attack. 
Although the combined application of $1.5 \mathrm{~kg}$ $\mathrm{ha}^{-1}$ carbofuran and $80 \mathrm{~kg} \mathrm{~N}^{-1}$ gave the highest fruit yield of $18 \mathrm{tha}^{-1}$, the use of $0.5 \mathrm{~kg}$ a.i. ha ${ }^{-1}$ carbofuran and/or $80 \mathrm{~kg} \mathrm{~N}$ ha-1 $^{-1}$ resulted in the highest marginal economic returns. Further application of carbofuran and/or nitrogen were uneconomical. Single application of $1.5 \mathrm{~kg} \mathrm{ha}^{-1}$ carbofuran was considered effective by Egwuatu (1982). The 1.5 rate was found significantly higher than the 1.0 rate or even the combination of 0.5 rate with $80 \mathrm{~kg} \mathrm{~N} \mathrm{ha}^{-1}$ in this study. The reduction in this minimum effective rate was attributed to the marginal cost implication as well as the interactive effects of nitrogen. Depending on concentration, nitrogen fertilisers could predispose a plant to disease or pest attack (Van Hezewijk et al., 2008). Other agrobotanical traits assessed also attained statistical significance with incremental doses of carbofuran and/or nitrogen probably due to their therapeutic effects on the pests and diseases of the crop.

\section{CONCLUSION}

The phenological relationship between okra growth and the incidence of flea beetles (Podagrica uniformis, Jacoby, and Nisotra sjostedti, Jacoby) are amply evident. Podagrica uniformis appears earlier than $N$. sjostedti, and their population is generally lower during the vegetative than during the reproductive stages of okra. Podagrica uniformis occurrs earlier on the plants and its population also depressed earlier at 9 weeks after planting. Nisotra sjostedti occurred later and the population increased rather dramatically, until sampling was discontinued. Carbofuran applied at $1.0 \mathrm{~kg} \mathrm{ha}^{-1}$ and above gives effective control of the flea beetles up to 5 WAP. Application of $80 \mathrm{~kg} \mathrm{~N}$ $\mathrm{ha}^{-1}$ and above favoured infestation after 5 WAP. There is no carbofuran $\mathrm{X}$ nitrogen interaction effect on flea beetle counts. Applications of carbofuran and/or nitrogen, on the other hand, increases fruit number, fruit weight, fruit yield, net marginal returns and earliness to maturity. Applications of $0.5 \mathrm{~kg} \mathrm{ha}^{-1}$ carbofuran and $80 \mathrm{~kg}$ $\mathrm{N} \mathrm{ha}^{-1}$ gives the best fruit yield harvest and net marginal return. The incidence of mosaic disease symptom is suppressed with increasing doses of carbofuran.

\section{REFERENCES}

Adebawoo, O.O., Salau, B.A., Adeyanju, M.M., Famodu, A.A. and Osilesi, O. 2007. Fruits and Vegetables moderates blood pressure, Fibrinogen concentration and plasma viscosity in Nigerian hypertensives. African Journal of Food, Agriculture, Nutrition and Development 7 (6):1-13.

Andrews, M. Raven, J. A., Sprent, J. I. and Lea, P. J. 2007. Is shoot growth correlated to leaf protein concentration? Trends in Plant Science 12:(12): 531-532.

Anon. 1972. Pesticide Manual. Basic Information on the chemicals used as Active Compounds of Pesticides. $3^{\text {rd }}$ Ed. Hubert Martin (Ed.), 701pp. Issued by British Crop Protection Council, Clacks Farm, Worcester England, UK.

Arapitsas, P. 2008. Identification and quantification of polyphenolic compounds from okra seeds and skins. Food Chemistry 110:1041-1045.

Brunt, A., Crabtree, K., Dallwitz, M.J., Gibbs, A.J., Watson, L. and Zurcher, E.J. (Eds.). 1996. Plant Viruses Online:Description and Lists from the VIDE Database. Version: 16th January 1997. http://biology.anu.edu.au/Groups/MES/ vide/

Ceccon, G., Ragga, A., Duarte, A. P. and Siloto, R.C. 2004. Effects of Insecticides at sowing on seedling pests and yield of off-season maize crop under no-tillage system. Bragantia, Campinas 63 (2): 227-237.

Draycott, A. P. and Christenson, D.R. 2003. Nutrients for sugar beet production: Soilplant relationships. Technology and Engineering. 242pp.

Egwuatu, R.I. 1982. Field trials with systemic and contact insecticide for the control of Podagrica uniforma and P. sjostedti (Coleoptera: Chrysomelidae) on okra. Tropical Pest Management 28 (2):115-121.

Egwuatu, R. I. and Taylor, T. A. 1976. Aspects of the spatial distribution of Acanthomia tomentosicollis stal (Heteroptera, Coreidae) in Cajanus cajan (Pigeon pea) Journal of Economic Entomology 69 (5):591-594.

Enwezor, W. O., Udo, E. J. E. J., Usoroh, N. J., Ayotade, K. A., Adepetu, J. A, Chude, V. O. and Udegbe, C. J. 1989. Fertiliser use and 
management practices for crops in Nigeria (Series no 2). Federal Department of Agriculture, Lagos, Nigeria. pp. 20-45.

Fajinmi, A. A. and Fajinmi, O. B. 2006. Incidence of okra mosaic virus at different growth srages of okra plants (Abelmoschus esculentus L. Moench) under tropical condition. Journal of General and Molecular Virology 2 (1): 028031.

Groot,C.C., de Marcellis, L.E. M., Boogaard, R. van denkaiser, W.M. and Lambers, H. 2003. Relative growth ratio (RGR) increased gradually with increasing plant $\mathrm{N}$ concentration. Plant and Soil 248(1/2):257268.

Jungerius, P.D. 1964. The soils of eastern Nigeria. Puld Service Geologique due Luxemburg XIV. pp. 185-195.

Lengsfeld, C., Titgemeyer, F., Faller, G. and Hensel, A. 2004. Glycosylated compounds from okra inhibit adhesion of Helicobacter pylori to human gastric mucosa. Journal of Agricultural and Food Chemistry 52 (6):1495-1503.

Marchie, D. C. 1993. Ecology, Epidemiology and control of okra mosaic virus in south-eastern Nigeria. Ph.D Thesis, Department of Crop Science, University of Nigeria, Nsukka.

Martin, F. W. 1982. Okra potential multipurpose crop for the temperate zone and tropics. Economic Botany 36:340-345.

Ndunguru, J. and Rajabu, A.C. 2002. Papaya ring spot virus disease in Lake Victoria basin. Tropical Science 42:11-16.

Prulovic, D. Popovic, M., Malencic, D. and Marinkovic, B. 2010. Effect of Nitrogen fertilization on the biochemical and physiological parameters in leaves and root of sugar beet associated with Azotobacter chroococcum. Journal of Plant Nutrition 33:15-26.

Schipper, R.R. 2000. African Indigenous Vegetables. An Overview of the cultivated species. Chathaam, UK: Natural Resources Institute/ACP-EO Technical Centre for Agricultural and Rural Cooperation. UK.

Steel, R.G. D. and Torrie, J. H. 1980. Principles and Procedures of Statistics ( $\left.2^{\text {nd }} \mathrm{ed}\right)$. McGraw-Hill Book Company Inc. New York, USA. 633pp.

Tisdale, S. L. and Nelson, W. L. 1975. Soil fertility and fertilizer. Macmillan Co. Inc New York (3 ${ }^{\text {rd }}$ Ed..), pp. 179-181.

Trevisan,M.J., De Baptista, G..C., Trevizan, L. R. P. and Papa, G. 2004. Residues of carbosulfan and its carbofuran metabolites and 3-hydroxycarbofuran in oranges. Revista Braileira de. Fruticltura, Jaboticabal - SP 26(2): 230-233.

Useche, A. and Shipley, B. 2010. Interspecific correlates of plasticity in relative growth rate following a decrease in nitrogen availability. Annals of Botany 105 (2):333-339.

Van Hezewijk, B. H., De Clerck-Floate, R. A. and Moyer, J. R. 2008. Effect of nitrogen on the preference and performance of a biological control agent for an invasive pla`nt. Biological Control 46:332-340.

Youdeowei, A. 2002. Integrated pest management practices for the production of vegetables. Ministry of Food and Agriculture (MOFA) Plant Protection and Regulatory Services Directorate (PPRSD) publications with German Development Cooperation. United Kingdom. 49pp. 